\title{
Problems in the Interpretations of Ottoman Rebellions in the Early Modern Period: An Analysis and Evaluation of Existing Literature on the Ottoman Rebellions between I550 and I82 I
}

\author{
Birol Gündoğdu*
}

There is not a single critical study of Ottoman rebellions that encompasses the entire history and genealogy of uprisings in the Ottoman Empire for the time period between 1550 and 1821 . Moreover, there has been almost no attempt at all to construct an explanatory template for "rebellions" in the Ottoman context, either. Nevertheless, during the time under consideration many studies of individual rebellions do exist, such as for the Celali rebellions of the sixteenth and seventeenth centuries; the insurrection of 1622, the 1703 Rebellion, the sekban and sarica rebellions, ayan rebellions, Patrona Rebellion of 1730, the 1740 Rebellion, the Morea Rebellion of 1770 and national rebellions of eighteenth and early nineteenth centuries etc. Our departure point in this paper is first articulate a full account of the Ottoman scholars and their noteworthy contributions to this discussion and then to highlight their shortcomings and gaps in order to construct a more comprehensive understanding of the Ottoman rebellions in the early modern Ottoman Empire. More importantly, however, this article is a pioneering attempt to express complexity and diversity of Ottoman rebellions through a better analysis of the existing literature. Thereby, we would like to open the door for alternative explanations of rebellions, which have been unaddressed before.

* Sivas Republic University (Turkey) and the University of Gießen (Germany). E-Mail: birolgundogdu@gmail.com 
Rather than discussing every single writing of Ottoman/European scholars who somehow deals with Ottoman rebellions, we will only focus on works of most noteworthy historians in order to contextualize and analyze Ottoman uprisings as responses to changing challenges and opportunities in the empire. That is to say, we shall scrutinize Mustafa Akdağ, Celâli İsyanları: (1550-1603) [1963], Robert W. Olson, "The Ottoman Empire in the Middle of the Eighteenth Century and the Fragmentation of Tradition: Relations of Nationalities (Millets), Guilds (Esnaf) and the Sultan, 1740-1768” [1976], William J. Griswold, The Great Anatolian Rebellion 1000-1020/1591-1611 [1983], Rifaat Ali Abou-El-Haj, The 1703 Rebellion and the Structure of Ottoman Politics [1984], Thomas Gallant, "Greek Bandits: Lone Wolves or a Family Affair?” [1988], Jack A. Goldstone, Revolution and Rebellion in the Early Modern World [1991], Karen Barkey, Bandits and Bureaucrats: The Ottoman Route to State Centralization [1994], Palmira Brummett, "Classifying Ottoman Mutiny: The Act and Vision of Rebellion" [1998], Ahmet Yaşar Ocak, "Kutb and Revolt: Some Thoughts on the Ideological Background of Ottoman Messianic Movements" [1999-2000] Jane Hathaway, ed. Rebellion, Repression, Reinvention: Mutiny in Comparative Perspective [2001], Gabriel Piterberg, "The Alleged Rebellion of Abaza Mehmed Paşa: Historiography and the Ottoman State in the Seventeenth Century" [2003], Selim Karahasanoğlu, Politics and Governance in the Ottoman Empire: The Rebellion of 1730 [2009], Baki Tezcan, The Second Ottoman Empire: Political and Social Transformation in the Early Modern World [2010], and Birol Gündoğdu, "A Boiling Cauldron of Conflicts and Cooperation: The Question of Two Distinct Societies during and after the Morea Rebellion of 1770" [2014]. We will follow a chronological pattern from the oldest works to more recent ones in order to bring into the sharp relief the changes in the way Ottoman/European scholars interpreted Ottoman insurgences over the course of time.

One of the earliest and most elaborate studies of Ottoman rebellions comes from Mustafa Akdağ, whose work covers an important period of the Celali uprisings between the years 1550 and 1603 . His approach to the subject can be best classified as an archetype of the traditional way of looking at Ottoman rebellions. He puts a great emphasis on the social and economic background of the uprising, where a drop in crop production, shortage of precious metals, trade deficit, abuses of the state or government officials are all presented as the very factors, which brought about both a general economic breakdown and Ottoman rebellions of the time. The crisis of the sixteenth century was not limited to the Ottoman state. 
Instead, there was a widespread economic depression based on the lack of fertility in the Mediterranean world at the very same time. However, unlike Europe, which succeeded in modernizing itself starting the second half of the sixteenth century, Akdağ states that the Ottoman Empire was neither able to follow the same path nor to have a capacity to move her labor force to new economic sectors. This common disorder and unrest in the empire gave rise to levendization (levend being landless vagrant peasant) of the Ottoman peasants. ${ }^{1}$

As a matter of the fact, Akdağ divides rebellions of the time into two parts and only explains one of them. Namely, he is not concerned with those rebellions such as Şeyh Celal and Baba Zinnun, which were largely based on religious ideology of the Shia sect of the Muslim population. These people professedly neither accepted the legitimacy of the Ottoman Empire nor had any personal connection with Ottoman high dignitaries. Instead, they aimed for the total destruction of the Ottoman dynasty and invariably refrained from any act of conciliation with Sunni Ottoman state. As for the Celali rebels, however, they neither challenged Ottoman right to rule nor had intention of demolishing the empire. Instead, they rather looked after their own self-interests in a time of difficult social and economic conditions. In this respect, unlike former religious uprisings their movements cannot be associated with any ideological and political destruction of the Ottoman Empire or attempts to establish a new government or an autonomous state. $^{2}$ That is why Celalis saw no harm in switching sides between rebels and loyal subjects of the Ottoman state. ${ }^{3}$ Akdag concludes that the Celali rebels neither created a coterie to fight against the state or Ottoman households nor became a nationalist movement militating against the devşirme institution. That is why he finds it more appropriate to use the term the "struggles" of Celali (Celali mücadeleleri) rather than Celali rebellions (Celali isyanlar). ${ }^{4}$

More than a decade elapsed until Robert Olson brought a new approach to Akdağ's way of explaining Ottoman rebellions where the empire beyond retrieve entered into first a period of stagnation and then decline. Olson's elaborate study

I Mustafa Akdağ, Celâlì İsyanları: (I550-I603) (Ankara: Ankara Üniversitesi Basımevi, I963), 44-48 and 68-72.

2 Mustafa Akdağ, Celâlî, 244-250.

3 Mustafa Akdağ, Celâlî, I-2.

4 Mustafa Akdağ, Büyük Celâlı̂ Karışıklıklarının Başlaması (Erzurum: Ankara Üniversitesi Basımevi, 1963), I. 
on the rebellion of 1730 as well as that of 1740 , however, indicate that the threat of rebellion not only caused more radical changes than being a tool to get a higher position in the state apparatus but also a total realignment of the traditional Ottoman foundations. To be exact, the rebellion of 1730 brought about a rearrangement of those groups either endorsing or opposing the sultan's policy of increased contact with Europe. Before 1730, major support of the sultanate had come from the military elite and the ulema. However, after that elements of the military elite, which opposed the introduction of European military techniques, and the ulemas who were opposed to infiltration of European customs and ideas in the Ottoman society began to collaborate with the anti-sultan forces. However, the esnaf (artisans) and merchants who had been some of the prominent opponents of the Sultan and Grand Vizier started to throw in their support with the new Sultan i.e., Mahmud I (1730-1754) when confronted with a threat to their businesses by continued disorder in Istanbul. Following the alignment of 1731, the 1740 Rebellion astonishingly resulted in the Sultan providing arms to non-Muslim guilds who in return assisted him in suppressing this devastating uprising. Olson interprets this switch of allegiance as one of the most sudden and significant changes of eighteenth century Ottoman history. He also finds the era under consideration indispensable for the understanding of the nationalistic movements of the nineteenth century and accompanying problems of modernization. ${ }^{5}$

Transforming an individual enemy into a friend and a single friend to an enemy in danger of a new rebellion is not totally unknown to us. Nevertheless, Olson's example shows us how widespread this phenomenon became at that time and how easily a substantial number of Ottoman Muslim and that of non-Muslim subjects changed their sides from supporting the government to bolstering rebels, and vice versa. In this regard, his study on the aforementioned rebellions are nothing less than a cornerstone, an essential element in the understanding of Ottoman rebellions and their huge impact on Ottoman societies. One can even describe that as a flexible relation among enemies, rivals and friends who could easily either take the side of the Sultan and or opposing his "absolutist" regime, if need be. Taken all into consideration, however, it is still both misleading and of limited value when we take the intricacy and complexity of Ottoman rebellions into consideration. More or less, Olson argues that the Ottoman society of the

5 Robert W. Olson, "The Ottoman Empire in the Middle of the Eighteenth Century and the Fragmentation of Tradition: Relations of nationalities (Millets), Guilds (Esnaf) and the Sultan, I740-1768," Die Welt des Islam I7 (1976-1977). 
time was somehow divided into two homogenous groups clearly defined according to their religious, group or other identity. On the one side we see esnaf and merchants mainly consisted of non-Muslim subjects of the empire and on the other hand, we see Muslim military elites and ulema. In practice, however, such united entities not only shared similar interests but also acted together by shifting sides either in favor of the Sultan or to detriment of his absolutist policies, only existed long after nationalism consolidated in the nineteenth and twentieth centuries. In other words, even the millet system, which is occasionally claimed to have strictly divided Ottoman subjects into two homogenous groups, is far from being a real obstacle for a member of certain religious or entity to turn his back to the group he actually belonged as we shall clearly observe in the writings of later scholars.

Exactly two decades later we see a more rational and critical approach to the Celali rebellions than Akdağ's preliminary work from William Griswold. On the one hand, he accepts many of Akdağ's traditional explanations for the question as to why the Ottoman system might have broken down in the sixteenth century, such as alterations in the tımar system, maladministration, scarcity of successful leaders, negative balance of trade because of bad effects of the European price revolution, etc. On the other hand, however, he also makes some valuable contributions to the discussion of the Celali İsyanlar, which he rather prefers to call the Great Anatolian Rebellions. While mainly conceding that the Celali rebels intended to be part of the Ottoman system in lieu of destroying it or founding a new state, Griswold also argues that there were some separatist rebels such as Canbuladoğlu Ali Pasha, who almost exceptionally aimed to establish an independent state of their own during the Celali rebellions. In other words, the Celali insurgents thought their interests matched up with the Ottoman Empire instead of Iran or the European states. Nonetheless, their ultimate target was nothing more than to find a favorable means to reenter the Ottoman state apparatus, which still remained as much more lucrative investment than any other enterprise of the Ottoman Empire. That is why Griswold does not think of Canbuladoğlu within the context of the Celali rebels of Anatolia. Canbuladoğlu's attempt to establish a new state is to be associated with personal reasons, such as retaliation for the execution of his uncle or his personal ambition of founding another state of his own in Aleppo. His ambitious path to detriment of the Ottoman state was later followed by other examples in the seventeenth century as well. In each case, the dynamics that brought about Great Anatolian rebellions 
and those of others are completely distinct from one another and should be also investigated separately. ${ }^{6}$

The extension of Griswold's study has explicitly shown that the Celali rebellion is a many-sided subject, which was either totally ignored or given too little weight by Akdağ before. For example, the Ottoman Empire was quite adapt at employing the tool of negotiation with the rebels, such as offering them official status (often for a very short period of time) in order to reintegrate some into the Ottoman system under more favorable terms (i.e. Zülfikar Pasha and Karakaş Ahmed. $)^{7}$ If it was not likely to happen, as a last resort the empire attempted to eliminate them, as it was the case in Canbuladoğlu Ali and Kalenderoğlu Mehmed. Furthermore, the Celali rebels were not alone but had important advocates and supporters among high dignitaries living in Istanbul and therefore they were even able to depose certain state officers or place them in jeopardy by making false claims about them. ${ }^{8}$ Last but not least, we even see the insurgents like Canbuladoğlu and Ma'noğlu Fahreddin as seeking support from external powers, such as the Shah of Persia in the East and the Duke of Tuscany in the West, in order to establish their own state in Aleppo. ${ }^{9}$ On balance, Akdağ selective idealization of those Celali rebels is to a certain degree denied by Griswold. Nonetheless, Griswold's single tangible example of Canbuladoğlu is more likely to be read as an exception among many Celali rebels who had arguably no intention to overturn the Ottoman dynasty and ruin the empire but rather exclusively looked for opportunity to upward mobility or career path within the state. Both Akdağ and Griswold argue that there was huge differences between the Ottoman Empire and its European neighbors as experiencing and coping with upheavals and rebellions of the early modern world. To large extent, the former had neither skill nor talent to follow the pattern of the latter, which came to be closely associated with glorious transformation and advance from ancient empire to modern state. Although the Ottoman state and its European adversaries shared many common historical experiences and turmoil Akdağ and Griswold agree that the Ottoman rebellions were simply a sign of the decline or a symbol of state transformation into something the state should have never turned to be. Consequently, they

6 William J. Griswold, The Great Anatolian Rebellion I000-I020/I59I-I6II (Berlin: Klaus Schwarz, I983), xxi-xxii.

7 Griswold, The Great Anatolian, 55-56.

8 Griswold, The Great Anatolian, I07-I08.

9 Griswold, The Great Anatolian, I28-I32 and I55. 
have been both heavily influenced by the "theory of Ottoman decline," which sees Ottoman rebellions as both forerunner to and verification for the breakdown of Ottoman domination. ${ }^{10}$ Needless to say, the decline paradigm (or "untrue myth" 11 as Howard called it) - which has been compellingly discarded by a substantial number of scholars - falls far short of providing us with a satisfactory explanation of the Ottoman rebellions in general since the Ottoman Empire was often quite competent at adapting itself to changing circumstances until its total disappearance from the world in $1922 .{ }^{12}$

Rifat Abou El-Haj and his study on a specific rebellion, the 1703 Rebellion, offer us one of first new approaches in the interpretations of an Ottoman rebellion made so far. He does not see this rebellion as an isolated incident but instead interprets it as an event, which revealed the structures and relationships of power within the Ottoman state at the time. El-Haj argues that domination of the vizier and pasha households had already prevailed for about half a century prior to the 1703 Rebellion. Accordingly, the changes in status and needs of the Ottoman state required different skills in its administrators and the result was the predominance of the households over traditional sources of recruitment. By the end of the seventeenth century, nearly half of all key posts in the central and provincial administration of the Ottoman state were staffed by the men who had been trained in and attached to at least one vizier-pasha household. They gained so much power that they not only deposed Mehmed IV (1648-1687), but also later posed significant obstacles to Mehmed's offspring i.e., Mustafa II (16951703) and Ahmed III (1703-1730). Domination of the political structure by the vizier and pasha households gave rise to the factions in the empire that in the long run carried out the 1703 Rebellion. Through either cooperating with other

Io Palmira Brummett, "Classifying Ottoman Mutiny: The Act and Vision of Rebellion", Turkish Studies Association Bulletin 22 (1998): 93.

II Douglas Howard, "Ottoman Historiography and the Literature of 'Decline' of the Sixteenth and Seventeenth Centuries", Journal of Asian History XXII (1988): I44.

I2 Traditional scholars often use Ottoman advice literature in addition to archival documents with no awareness of their essentially literary character. The way that we should approach these sources are well discussed by several scholars of importance. See for example, Rifaat Ali AbouEl-Haj, "The Ottoman Nasihatname as a Discourse over "Morality"”, Mèlanges Robert Mantran (Revue d'Histoire Maghrebine), (1987); Pál Fodor, "State and Society, Crisis and Reform, in $15^{\text {th }}$ $17^{\text {th }}$ Century Ottoman Mirror for Princes", Acta Orientalia Academiae Scientiarum Hungaricae 40 (1986); Suraiya Faroqhi, Approaching Ottoman History: An Introduction to the Sources (Cambridge, New York: Cambridge University Press, 1999). 
factions or fighting against their opponents, various factions tried to assert both their supremacy and their privileges in the Ottoman state. El-Haj puts forward that the rebellions begun either to strengthen a position in jeopardy or to secure a newly won position over the other faction(s). ${ }^{13}$

Most important of all, however, El-Haj describes the Ottoman household nothing more than another faction among many factions, which were all vying for supremacy in the Ottoman Empire. In this respect, El-Haj argues that such rebellions might have been a major challenge to the very existence of the Ottoman dynasty as well. Namely, there were the times when the empire in general and the Ottoman dynasty in particular remained under great danger of being totally destroyed. In this respect, it not only serves as an innovative model for other continuing studies of Ottoman uprisings but also as a primary example to prove Brummet's case as we shall see soon. More importantly, it clearly puts forward that even a single study like the 1703 Rebellion might have so many aspects and facets, which cannot be reduced to a single theory or an argument, let alone some of the aforementioned explanations made for the time period under consideration. After all, the 1703 Rebellion exposed the reduced power of the Ottoman household. From this point onward, the Sultan had no choice but to take the advice of increasingly powerful citizen groups if he wanted to carry out the business of government with any effectiveness. As a result, the palace and the military had taken secondary roles in both the formulation and execution of policy. El-Haj concludes that the 1703 Rebellion not only brought about a more decentralized state but also further secured the predominance of the viziers and pasha households as well as the ulema in the empire. ${ }^{14}$

In a similar vein, Thomas Gallant further contributed to the study of rebellion particularly about four years later by diversifying and deepening the arguments made by El-Haj. He argues that rebels did not have a special importance that might force us to think of them as a separate entity from peasant societies. Most important of all, however, Gallant finds a close relationship between kinship and rebels, as opposed to many others who frequently describe rebels as freedom fighters. ${ }^{15}$

I3 Rifaat Ali Abou-El-Haj, The I703 Rebellion and the Structure of Ottoman Politics (Leiden: Nederlands Historisch- Archaeologisch Instituutte Istanbul, 1984), 9-IO.

I4 Abou-El-Haj, The 1703 Rebellion, 9I-92.

Is See for example Eric Hobsbawn, Bandits (Harmonsworth: Penguin Books, 1969), 73. 
His examination of sources other than rebel songs demonstrates that Greek bands exclusively consisted of relatives, who were an integral part of society, not isolated groups separate from their communities. His examples such Kolokotronis and Mavromati clearly indicate that the Greek gangs operated only with those descended from the same ancestors, related by marriage or at least with a fabricated family member. ${ }^{16}$ His conclusion is as important as his analysis. Namely, consanguineous relations were to be found at the heart of rebellious gangs and anyone else, not connected with them (either through marriage or through blood) was thought of as an enemy until proven otherwise. In a similar vein to the peasant family, the rebels established a special social network, which rather proved that rebellious act might have been only a family affair rather than anything else. ${ }^{17}$ In a similar vein to El-Haj's pasha household where blood ties can also be seen one of its lubricants, Gallant's conclusions reveal the fact that natural human instincts (such as having a common ancestor, as it is the case here) might offer us more significant and plausible explanations than traditional arguments made for the rebellious acts so far. After all, most activities of rebels that we have taken into consideration in this article can be much more easily explained if we take kinship or more personal relations among insurgents into consideration instead of overemphasizing political and religious ideology or communitarianism, which are more likely to be full of exceptions.

About three years later Jack Goldstone also not only continues to fight against traditional explanations of the Ottoman rebellions but also Eurocentric notions of seventeenth-century crisis, where the presence of war and the growth of capitalism are often given as the reasons for dynamic structural changes in Europe. Instead, he accepts a global crisis of agrarian absolutist states that had an effect upon not only empires in the East but also in the absolutist West. As a matter of the fact, the whole early modern period was full of consecutive crises. However, among these successive crises there were two marked "waves" of state breakdowns on a worldwide scale. The first one happened in the period 15501650 , which was later followed by a century of stability; the second wave of crises took place in the period after $1750 .{ }^{18}$ More importantly, however, Goldstone

I6 Thomas Gallant, "Greek Bandits: Lone Wolves or a Family Affair?," Journal of Modern Greek Studies 6/2 (1988): 269-274.

I7 Gallant, "Greek Bandits", 28I-284.

I8 Jack A. Goldstone, Revolution and Rebellion in the Early Modern World (Berkeley: University of California Press, I99I), I-I7. 
finds remarkable similarities the way state breakdowns took place in the Eastern and Western states. He argues that previous widely accepted explanations of early modern history fall far short of elucidating the state breakdown. For instance, he does not accept the "military revolution" of the sixteenth century as an explanation for increasing costs of the war, which later arguably brought about state fiscal crises. Instead, he argues, population growth not only increased the number of soldiers taken under arms but also directly caused a rapid increase in military spending. Goldstone concludes that the incapacity of agrarian economies and of their attendant social and political institutions to cope with the pressures of this sustained population increase led to state breakdowns. ${ }^{19}$ More significantly, as far as our topic is concerned, he posits that all political and social turmoil that emerged from this uncontrollable population increase led to persistent price inflation, rural misery, urban migration, as well as fiscal crisis, as it was the case in the Ottoman rebellions. ${ }^{20}$

Goldstone puts into question the orthodox explanation of rebellions in terms of class struggle, new martial technologies, capitalism, silver exports from America to Europe or a shift in trade, which are more or less taken as driving forces largely by Akdağ, and Griswold. Instead, he totally denies many traditional triggering factors in the Ottoman rebellions and explains everything with one single factor of population growth, which agrarian-bureaucratic states were not in a positon to cope with successfully. Accordingly, he finds no correlation to importations of excessive amounts of silver from America, by positing that prices either remained the same or were reduced in many states in the late seventeenth century. It was not excessive silver but the scarcity of grains resulting from the population pressure that increased the prices dramatically. ${ }^{21}$ Again, we observe a decrease in taxation and an increase in state expenditures due to the increased

I9 Goldstone, Revolution, 2O-2I. As a matter of the fact, the idea of population pressure for Mediterranean countries is first stated by Fernard Braudel. However, having done research for the years I450-1575 of villages in Anatolia, M.A. Cook argues in particular that "population growth was more rapid than the extension of cultivation" and consequently there was a considerable population pressure on the Anatolian plateau because the population grew faster than the extension of arable land. Although he accepts population pressure as one of the most important factors for the explanations of the breakdown in social order, he does not see population pressure as "the only possible precipitant". M. A. Cook, Population Pressure in Rural Anatolia, I450-I600 (London, New York: Oxford University Press, 1972), IO and 43.

Goldstone, Revolution, 25-26.

Goldstone, Revolution, 36I-362. 
number of salaried imperial troops. ${ }^{22}$ All these conditions paved the way for the emergence of popular uprisings, with the help of increasing landless and impoverished peasants and the incapacity of the Ottoman agrarian economy to cope with the population pressure. ${ }^{23}$ In this regard, there was no noteworthy differences among Europe, China and Ottoman Empire from 1500 to 1850, all of which experienced popular unrests on account of population growth and its accompanying destructive effects. Unlike Akdağ and to large extent Griswold, therefore, Goldstone describes the Ottoman Empire as economically and administratively as sophisticated as European states (and even more superior than the West until the very end of seventeenth century). In this sense, his book can be regarded as a preliminary work of Barkey who shall also argue that the Ottoman Empire was quite good at adapting to new eras for the very purpose of maintaining its integrity and of surviving severe setbacks.

All things considered, however, Goldstone's attempt to explain the socio-economic and political turmoil that took place in the Ottoman Empire for a period of three centuries simply does not stand the test of Ottoman realities at that time. Suffice it to say that his two marked "waves" of state breakdowns, i.e., 15501650 and 1750-1850, with a century of stability in between, is far from being a satisfactory explanation for one of the most chaotic periods of the Ottoman Empire (1650-1750). In other words, his periodization (and overgeneralization) of rebellions for all of them in the period 1550-1650 as well as that of 1750-1850 is full of exceptions, irregularities and interruptions, which is neither a reasonable nor a consistent answer to the question of the causes of state breakdown. Indeed, Goldstone's overemphasis upon population growth does not work for other European states either. To give but one example, Niels Steensgaard posits that the seventeenth-century crisis was not a worldwide reversion to backwardness since it is not possible to identify a certain period of time hit by a general economic depression. Conversely, we can even observe substantial economic advances and an expansion in various sectors of European states at different times and to a different extent. Steensgaard concludes, "the seventeenth century crisis was a distribution crisis, not a production crisis." ${ }^{24}$ Although Goldstone's overgeneralization on the population increase is quite a problematic one his emphasis

22 Goldstone, Revolution, 365-367.

23 Goldstone, Revolution, 355-357.

24 Niels Steensgaard, "The Seventeeenth-Century Crisis", in The General Crisis of the Seventeenth Century, Lesley M.Smith Geoffrey Parker (eds.) (Hoboken: Routledge, 1997), 36-45. 
that Ottoman Empire, Europe and China somehow experienced the same wave pattern of disorder and stability is a valid one. At least, he teaches us that popular unrest and revolt in the Ottoman Empire can no longer be seen as isolated phenomena and we can reasonably approach this topic from a more comparative perspective as one might easily observe perceptible similarities (and differences of course) among them.

This is exactly what Karen Barkey succeeded in three years later. To be exact, Barkey has brought out a new (but not totally unheard) dimension to conventional concepts of previous approaches. As comparing Europe with the Ottoman Empire, she rather emphasizes dissimilarities between both and finds the latter was much more successful to keep rebels under tight control. Accordingly, European states first followed a more feudal pattern where noblemen dominated the state apparatus then moved to a more direct centralized pattern where government officials controlled the state administration. However, the Ottoman state was first controlled with state appointed officials and then a mixed center-periphery control gained currency. Eventually, we see the indirect control of the state apparatus by means of provincial elites. ${ }^{25}$ Again, unlike the European states the Ottoman Empire neither encountered anti-feudal or anti-state resistance nor experienced peasant or elite defiance on account of patrimonial characteristics of the Ottoman state. Ultimately, she concludes the Ottoman Empire should be more aligned with the Russian and Chinese empires rather than the European powers. $^{26}$

More importantly, however, Ottoman strategies of incorporating peasants and rotating elites, as Barkey puts forward, not only consistently kept those citizens dependent on the state but also prevented the devastating impacts of the rebels, who were more concerned with gaining state resources rather than challenging state authority. In other words, through deals, bargains, and patronage, which are seen as signs of strength rather than weakness, the Ottoman Empire was able to "present itself as the sole center for rewards and privileges." 27 On the contrary, Barkey states that the Ottoman Empire not only used rebels as a part of an ongoing process of state consolidation, but also actively incorporated them

25 Karen Barkey, Bandits and Bureaucrats: The Ottoman Route to State Centralization (London: Cornell University Press, 1994), 2.

26 Barkey, Bandits, 8-9.

27 Barkey, Bandits, I3. 
into its strategies of state centralization. Accordingly, she repeatedly argues that insurgents in the Ottoman Empire consistently made a strong comeback into the Ottoman system. The empire used them in order to both centralize its power and maintain its predominance over scattered regions of the empire, which ergo developed an imperial state centralization at least in the seventeenth and even eighteenth centuries. ${ }^{28}$ Consequently, there is no reason to posit that the empire experienced any sort of state breakdown (but only setbacks) - in direct opposition to the arguments made by Goldstone. ${ }^{29}$

Although Barkey's arguments are quite useful in terms of revealing how talented the Ottoman statesmen were to cope with the crisis of seventeenth century and of highlighting the shortcomings of the "decline paradigm," which is unquestioningly and uncritically accepted by many Ottoman scholars including Akdağ, Griswold and to some extent Olson. Nevertheless, her over optimistic evaluation of all Ottoman rebellions in the seventeenth century does not really explain plethora of serious threats that the empire experienced at that time. These threats, which are without exception called "the fictions of historians," 30 not only occasionally succeeded in disgracing, deposing and even murdering Ottoman sultans but also frequently in unseating, expelling and executing the most significant dignitaries of the empire. In opposition to El-Haj and Griswold, Barkey neither gives a clear description of uncompromising revolts nor deliver an opinion on those rebels, who either intended to establish their own independent or semi- independent states or utterly refused to accept the Ottoman dynasty as a legitimate government. On balance, Barkey has a blinkered view that excludes important exceptions, which highly shatter credibility of her arguments. As we will shortly see, Piterberg's research on the military rebellion of 1622 and his study on Abaza Mehmed Pasha not only provide vivid examples of complex and multifaceted nature of Ottoman rebellions but also display that one cannot rightly comprehend Ottoman unrests with a single "binary opposition" of Barkey.

One of the first comprehensive attempts to understand Ottoman rebellions in general comes from Palmira Brummett four years later after Barkey. She tries to suggest a provisional categorization of Ottoman rebellions by means of scrutinizing some earlier accounts of uprisings. First and foremost, she clearly points

28 Barkey, Bandits, I8-19.

29 Barkey, Bandits, 19 and 238-239.

30 Barkey, Bandits, 24I. 
out that rebellions in the Ottoman Empire were much more diverse and various than many studies like to claim so far. For instance, salary, food, the desire to go home, injustice or cruelty might only partially explain mutinies. There were the insurrections, which were not seen as an attack against the Ottoman state, but as the intent to be integrated within the state. Yet, there were those uprisings, which targeted the very existence of the empire and there were others, which only came into existence at certain times and places with completely different criteria, etc. On the one hand, she also argues, the state first tried to minimize or alleviate resentment. Afterwards, the state used its weapons of either negotiation or threat. On the other hand, rival groups used the rebellions in order to expand both their power and prosperity. It was "a calculated risk" where one can win or lose everything. More importantly, however, both sides preferred negotiation and comprise, and abstained from going all the way through either to suppress the uprising at all costs or to turn it into a revolution against the very existence of the state. ${ }^{31}$ Brummett's arguments are critical in revealing the fact that rebellions are both diverse and complicated and more importantly, each uprising is of its own kind and should be scrutinized accordingly. However, her article does not bring anything other than encapsulating the arguments of Ottoman rebellions in a systematic and structured manner. Hence, her writing is subject to all sorts of restraints that we have seen so far in this article.

Ahmet Yaşar Ocak highlights a completely different aspect of the Ottoman rebellions that Brummett, Akdağ and Griswold either totally ignored or gave very little attention. At the outset, Ocak makes a clear distinction between isyan (rebellion) and kiyam (revolt). He puts forward that these two terms cannot be seen as one and the same as it is now, since they had different connotations at the time they were used. That is, isyan is referred to those armed movements, which emerged because of the oppressions of central state. Nevertheless, kryam is thought of referring to those armed uprisings, which did not stem from state pressure or injustice but which rather carry a direct political aim with an ideological background and messianic inspiration. ${ }^{32}$ Accordingly, the sufi kiyams not only entirely denied the legitimacy of the Ottoman dynasty but also totally rejected both the religious and earthly power of Ottoman sultans. ${ }^{33}$ Although

3I Brummett, "Classifying Ottoman Mutiny: the act and vision of rebellion," IO4-IO7.

32 Ahmet Yaşar Ocak, "Kutb and Revolt: Some Thoughts on the Ideological Background of Ottoman Messianic Movements," Toplum ve Bilim 83, (1999-2000): 48.

Ocak, “Kutb”, 54. 
these revolts also took advantage of the discontents among Ottoman (especially heterodox) subjects, their departure point was not to force the state to carry out any needed reforms and to eliminate injustice for the good of their supporters. Instead, using the imagery of the mabdi (Islamic messiah) they wanted to provide the formation of alternative power centers. Not surprisingly, in opposition to opponents' tendencies to cooperate rather than to compete with one another (as claimed by Brummett), first kind of Celali uprisings (as described by Akdağ) and their separatist species (as pointed out by Griswold) Ottoman response to the sufi revolts was neither conciliatory nor moderate in the sense of trying to coopting them into the Ottoman system once again. In other words, Ottoman answer to all potential threats coming from these sufi movements was so rigorous that the empire not only unhesitatingly executed their followers but also compelled Ottoman intellectuals to create counter arguments against the ideologies created and bolstered by members of the kiyams who had provoked their henchmen and tried to attract new followers for their cause. More importantly, the empire did not interpret them as a reflection of social and political change and instead as a "revolt" against state legitimacy and ideology as well as its "true orthodox religion". ${ }^{34}$

At the outset, however, one cannot strictly define meanings of words used in Ottoman sources since Ottoman intellectuals of the time were more than flexible to use certain Arabic and Persian vocabularies (and even native Turkish words) with highly flexible meanings. To reflect a valid distinction in the meaning and use of the words kryam and isyan is not even likely to be achieved for a single Ottoman thinker, let alone talking about all Ottoman intellectuals who always take such distinction into consideration as creating their accounts on kutb and revolt. Ocak's citations extracted from only a few booklets such as Sergüzeşt and Etvâru'l-Melâmiyyîn ve Esrâru'l Îlâhiyyin are far from making such a general assumption on sufi kiyams the way Ocak intends to do Ottoman rebellions with concrete examples extracted from the Ottoman archives. Hence, at its best his article could not achieve anything other than manifesting understandings of a few Ottoman thinkers including La'lizâde and Mustafa el-Üsküdârî. It is not surprising, therefore, that his classification of Ottoman rebellions is not later found worthy of consideration by the other scholars, who are one way or another interested in Ottoman rebellions thereafter.

34 Ahmet Yaşar Ocak, Osmanlı Toplumunda Zındıklar ve Mülhidler: (I5-I7. Yüzyıllar) (Istanbul: Tarih Vakfı Yurt Yayınları, 2003, vii-x. 
This does not necessarily deny the fact that one can bring a reasonable solution to the drawbacks of the previous approaches as Jane Hathaway did only one year after Ocak. Having accepted the complexity and intricacy of rebellions, Jane Hathaway sets forth several universal features of Ottoman rebellions. Firstly, rebellions did not come into existence out of nothing but instead there are arguably certain common characteristics at the heart of all insurrections, such as scarcity of material, a dearth of foodstuffs, deferred payments, etc. More significantly, though, enduring financial problems, unending wars, class inequality as well as newly emerged ideologies of nationalism or revolution stood against traditional regimes. Thereupon, a sense of unbearable injustice imposed upon a considerable number of people is also compulsory for a national uprising to take place. Besides, she describes Ottoman revolts as restricted phenomena rather than a massive social revolution. After all, we do not observe a revolution in the extreme sense of a violent and permanent subversion of the entire structure of the Ottoman Empire. ${ }^{35}$

Above all, even after a rebellion takes deep root and follows a series of violent actions, insurgents usually desire an agreement with the state, such as by demanding the attention of the rulers instead of going to extreme, murderous ends for the purpose of acquiring a radical transformation. To give an example, the Ottoman Janissaries' ritualistic regulation of refusing the sultan's food before taking action opened the way for negotiation and bargaining between government officials and rebels. In this way, both sides were given an opportunity to shield the state from more serious occurrences. ${ }^{36}$ However, despite all these factors enumerated above, she concedes, the rebellions might have been very harmful to the state. They occasionally caused the dethronement of one sultan in favor of another one, murders of sultans, replacement of ruling dignities with others, creation of new political and economic institutions, a new structure with new personnel and so on. Such serious consequences of the rebellions cannot be seen as consolidating the Ottoman power nor in harmony with traditional Ottoman structure. Furthermore, she fails to give any attention to other less mentioned but equally important factors like personal ambition and interests or consanguineous ties and ties of marriage, sense of belonging to certain community or ideology etc. as a driving force behind a myriad of insubordinate behaviors as penning an

35 Jane Hathaway (ed.), Rebellion, Repression, Reinvention: Mutiny in Comparative Perspective (Westport: Praeger, 200I), xv-xvi.

36 Hathaway (ed.), Rebellion, xvi. 
article which is supposed to classify most of Ottoman insurrections throughout its long history.

After El-Haj, Gabriel Piterberg's elaborate study on the Janissary insurrection of 1622, which first caused the dethronement of young ruler, Osman II (16181622) and tragically soon after his assassination, for the first time brought a new breath to concept of Ottoman rebellions. In the first part of his book, which is also claimed to "serve as a 'historical laboratory' for some of the most significant questions and processes that preoccupy Ottoman scholarship," 37 he discusses and elucidates the significant changes in the sultanic power and the Ottoman Empire in general in the period $1550-1650$. In this manner, it goes hand in had with previous scholars including Barkey and to some degree Goldstone. Namely, Piterberg does not explain the Ottoman state within the paradigm of "decline" nor sees any state "breakdown" during the time at issue. He also agrees with Akdağ and Griswold that first Celali rebels of 1596-1610 more or less worked in harmony with state's target of keeping a tight rein at the central and regional levels.

In the second part of the Celali rebellion, which approximately took place between 1620s and 1640s, however, Piterberg argues for the existence of a completely new type of rebellion in the empire. That is, after destruction of first Celali bands at the hand of the grand vizier Kuyucu Murad Pasha we see new rebels who worked in cooperation with pasha households. ${ }^{38}$ His chief example Abaza Mehmed Pasha (governor of Erzurum), who not only survived the total suppression of Celali rebellions but also created a career of his own in the pasha household by taking hand in marriage with a daughter of Gürcü (the Georgian) Mehmed Pasha's brother, was no longer a rebel in the sense of Celali rebels as it had been before but rather became a "provincial Osmanlı." Abaza's close relation with high state officials rescued him and many of his collaborators from perishing at the hands of the kul (officials in sultan's service, Janissaries), who had gained too much strength following the regicide of Osman II and whose control and power over the state apparatus now needed to be checked by all means. At this juncture, it was through Abaza Mehmed Pasha and his colleagues that "old Ottoman politics of balance and counterbalance" was successfully put into practice

37 Gabriel Piterberg, An Ottoman Tragedy: History and Historiography at Play (Berkeley: University of California Press, 2003), I.

38 Piterberg, An Ottoman, I57-I59. 
once more. ${ }^{39}$ Here, Piterberg accuses Barkey of excluding Abaza's story in which he affirmed his place within the state as having obtained "an Osmanlı socio-cultural status." Moreover, he disapproves of Barkey's "positivist approach" to her Ottoman historical sources. That is, having used merely the informational side of these historical texts and ignoring their ideological parts, Barkey is far from understanding the "historical corpus" of these sources, which are firmly connected with one another. ${ }^{40}$ On balance, Piterberg is quite able to combine advantages of the arguments made by Gallant as highlighting potential role of kinships for rebels and that of El-Haj as putting emphasis on pasha household in the example of Mehmed Pasha and his companions. At its best form, therefore, his conclusion on the rebellion of 1622 can be seen as a good amalgamation of former assertions written about 20 years before his book.

In the introduction of his book the Politics and Governance in the Ottoman Empire, which presents a new account on the Patrona Rebellion, Selim Karahasanoğlu analyses the rebellion of 1730 and its immediate impacts on the Ottoman Empire in detail. He brings an alternative view to traditional explanations of the Patrona rebellion which more or less took its last form in the writings of Münir Aktepe more than 50 years earlier. ${ }^{41}$ In direct opposition to some widely accepted theories made so far about the nature of the insurrection in issue, he persuasively claims that "the rebellion was not a struggle over morality and consumption but over power and governance." 42 Similar to El-Haj and Brummett, Karahasanoğlu posits that it is a struggle of different groups/households on the purpose of getting rid of their chief opponents in favor of their fellowmen. That is why the new faction immediately after the successful uprising did not like to keep anyone in their former position who had been one way or another associated with previous administration of Ibrahim Pasha and his comrades. ${ }^{43}$ Finally, he does not see the Rebellion of 1730 as "people's revolt" and their response to the ruling elites who

39 Piterberg, An Ottoman, I75-I76.

40 Gabriel Piterberg, "The Alleged Rebellion of Abaza Mehmed Paşa: Historiography and the Ottoman State in the Seventeenth Century", in Mutiny and Rebellion in the Ottoman Empire, Jane Hathaway (ed.), (Madison, Wisconsin: University of Wisconsin-Madison, 2002), 22-23.

4I See Münir Aktepe, Patrona İsyanı (I730) (Istanbul: Edebiyat Fakültesi Basımevi, 1958).

42 Selim Karahasanoğlu, Politics and Governance in the Ottoman Empire: the Rebellion of 1730 (Cambridge: Harvard University 2009), 2.

43 Thus, the new rule was cleansed of the old: "they did not want any of those who had been in the employ of Ibrahim Pasha to be given any appointments...” Karahasanoğlu, Politics, 9. 
had exploited the masses and the state to their personal advantages and benefits for such a long period of time. In this respect, he denies one of the most repeated causes of Ottoman rebellions (i.e., unbearable economic burden imposed upon ordinary subjects of the empire), which has been without exception taken for granted in the primary and secondary sources before. Instead, it should be regarded as "a struggle within a clique in the upper circles" rather than anything else. ${ }^{44}$ As a result, his work shows that even the most widely accepted motives of Ottoman rebellions as it is the case here in the Patrona Rebellion could be easily put into question and even entirely rejected as they are frequently unlikely to be aligned with historical norms and entries. In a similar vein, it is quite usual to see that one particular argument of Ottoman rebellions valid for a certain period of time can be later partially or totally refuted by another one. Karahasanoğlu's book is ergo a good example to prove that many widely accepted considerations in the literature, which mostly based on ideology, assumptions, overgeneralization, and even fictions, do not actually work for a comprehensive understanding of the uprisings in the study of Ottoman rebellions. Consequently, we should be ready and eager to review and revise even the most accepted arguments of Ottoman rebellions from top to bottom, just like Karahasanoğlu and his elaborate studies on the Patrona Rebellion of 1730.

In a similar manner to Karahasanoğlu just one year later Baki Tezcan also puts Osman's regicide and its consequences in the center of his book the Second Ottoman Empire: Political and Social Transformation in the Early Modern World. He argues for the existence of a wide-reaching transformation process in the Ottoman Empire, which roughly took place between the late sixteenth and seventeenth centuries. At the end of this process, Ottoman polity so dramatically changed its administrative, cultural, economic, monetary, political, legal and social structures that he prefers to give it a totally new name, i.e. "the Second Empire." ${ }^{25}$ The dethronement of Osman II in 1622, which is seen as success of "constitutionalist opposition to the absolutists," 46 played a crucial role (maybe a turning point) in this transformation of the political structure. It is not that easy to draw a strict line who supported whom but rebels of army forces desired to legitimize their act by either directly forcing or inviting some jurists to participate

44 Karahasanoğlu, Politics, I6.

45 Baki Tezcan, The Second Ottoman Empire: Political and Social Transformation in the Early Modern World (New York: Cambridge University Press, 20Io), , $о$.

46 Tezcan, The Second, II. 
their cause. It is not likely to argue for the existence of a close coalition between these two groups, which did really want to go all the way to the dethronement of the Sultan in opposition to many arguments thoroughly uttered in this paper so far. $^{47}$

At the outset, there was no immediate response to the deposition and murder of Sultan Osman. Soon after, however, relying on his sekban (provincial militia equipped with firearms) soldiers Abaza Mehmed Pasha seeking justice and avenge for the murder of Osman II led a rebellion against the central military corps of Janissaries who were also found responsible for any tumult in the empire at that time. Although he was not successful to get rid of Janissary corps and was soon captured by grand vizier Husrev Pasha (1628-1631) to be brought into the capital, his life was spared in favor of the absolutist in the reign of Murad IV (1623-1640). This was neither first nor the last conflict between the constitutionalist and absolutist supporters of the state. His analysis on the Janissary rebellions in the seventeenth-century Ottoman Empire is indispensable to understand place of the deposition of Osman II in this large picture. Murad IV's attempt to dismiss Husrev Pasha (an important protector of the military corps) in favor of Hafiz Ahmed Pasha (former supporter of Osman II) in 1631 is perceived as another action to establish an absolutist regime to detriment of the Janissaries. Once again, rebels succeeded in having three men executed against the will of Sultan Murad. In response, the Sultan not only got rid of high state officials including a grand mufti for the first time in the Ottoman history but also his brothers, potential candidates of the Ottoman throne. This did not bring about an absolute success to the supporters of absolutist politics though. The reign of his successor Ibrahim I (1640-1648), who also desired to centralize the state ended with his regicide as a result of another coalition made between army and a large number of ule$m a$. After that, we observe an autocratic rule of Köprülü family whose members exclusively occupied the grand vizierate almost without interruption until the beginning of the eighteenth century. Neither Mehmed IV (1648-1687) (who was also deposed, this time peacefully) nor Süleyman II (1687-1691) and Ahmed II (1691-1695) was able to break absolutist authority of Köprülü viziers and solely remained as their junior partners named as "symbolic leaders." Another attempt to establish royal absolutism took place in the reign of Mustafa II (1695-1703), which once again came to an end with a deposition of the Sultan. The limitation

47 Tezcan, The Second, 167 and I7I. 
of the royal authority throughout the seventeenth century in the interest of jurists is well described in Tezcan's quotation that "Mustafa II came to be deposed, among others, by a jurist whose father had deposed his father and whose grandfather had deposed and executed his own grandfather." 48 Following the 1703 incident, the Janissaries established a new form of government by directly electing Çalık Ahmed Pasha as the Commander of Janissaries (Yeniçeri A $\breve{g} a s \imath$ ) who used to be assigned by the Sultan before. It was an idea of system change where neither Sultan himself nor members of Ottoman family were considered indispensable for the existence of the state. Instead, Tezcan argues, Ahmed Pasha had a plan to turn the sultanate into a janissary oligarchy ("Janissary republic") that would elect its own leader. Even though this was only an aspiration of a single Janissary A $\breve{g} a$, his plan was not only taken quite seriously by his contemporaries but also seen as an important sign to prove uncontrollable power the Janissary corps at that time. ${ }^{49}$ This excessive consolidation of the power at the hands of constitutionalists, which can no longer be explained within the paradigm and theory of Barkey, Akdağ or Griswold as mentioned above, leaves the door wide open for alternative interpretations like Gallant's study did more than twenty years ago.

This constant struggle between the absolutists and constitutionalists described by Tezcan can also be explained as cooperation between two distinct family members of Ottoman society, who either supported the Sultans and their centralized rule, or members of military and learned class and their oligarchy. After all, among members of each group there was a bound of blood brotherhood. Many Ottoman Sultans wanted to take the advantage of a blood tie in order to consolidate their authority by eliminating or at least pacifying the pasha households and vice versa. For instance, in order to consolidate his authority and to assure the loyalty of Ottoman statesmen to the dynasty Ahmed III offered his thirty daughters to them, many of whom even more than once married high-ranking state officers after being widowed. Thereby, we see emergence of a new stratum that who were much more eager to serve the Ottoman dynasty with utter faithfulness and obedience because they had access to the rewards of association with the royal dynasty. ${ }^{50}$ To make long story short, the early modern Ottoman Empire experienced two conjoint phases of "the expansion of the political nation (or a

48 Tezcan, The Second, 220.

49 Tezcan, The Second, 213-226.

50 Caroline Finkel, Osman's Dream: The Story of the Ottoman Empire, I300-I923 (New York: Basic Books, 2006), 338-339. 
relative democratization of political privileges) and the limitation of royal authority," which shared several significant things in common with contemporary Europe. At the end of these developments where the legitimacy of a particular sultan could be frequently put into question through revolts against the government, which was ironically used to explain more than sixth-century longevity of the Ottoman dynasty. Accordingly, the dynasty turned to be something like a popular state where an Ottoman ruler could not only be easily deposed but also executed (if need be) to be replaced by another one. Nonetheless, it serves no purpose to get rid of the dynasty once and for all or to threaten the very existence of the dynasty, which still offered unprecedented access to privileges and prerogatives. ${ }^{51}$ On the one hand, Tezcan's argument carries us a step further than Barkey (and even to some extent El-Haj) who under any circumstance sees the position of the Ottoman dynasty in the state as inviolable or untouchable. If we take for granted the fact that the Ottoman dynasty survived till 1922 and interpret the past from that points of view, this assumption might be counted count as plausible and credible. As Tezcan thoroughly tested in many Ottoman rebellions, Ottoman insurgents or (adherents of a faction in this case) did not really have any unapproachable and sacred or spiritual border, which could under no circumstance be crossed. On the other hand, however, his claim for the existence of two totally distinct societies i.e. constitutionalists and absolutists steadily competing for gaining the upper hand in the Ottoman Empire is still problematic one as we shall see in my article published four years after Tezcan's book first published in 2010.

My comprehensive study on the Morea Rebellion of 1770 clearly indicates that to argue for the existence of any united/homogenous group of people delineated according to their religion or nation (or any other vaguely defined group identity of people) is neither reasonable nor accurate to expect even for the time period nearly two centuries after the Osman's regicide in 1622 or fifty years after the rebellion of $1730 .{ }^{52}$ That is, members of certain defined group did not really refrain from cooperating with members of the other groups or institutions that are frequently depicted as their archenemies. Ottoman primary sources of the time do not allow us to categorize certain Ottoman subjects and to differentiate them totally from others, the way Olson (and to a less extent Tezcan and

5I Tezcan, The Second, 237-238.

52 Birol Gündoğdu, "A Boiling Cauldron of Conflicts and Cooperation: the Question of Two Distinct Societies during and after the Morea Rebellion of 1770", International Journal of Turkish Studies 20 (2014): 67-84. 
Karahasanoğlu) like(s) to do for the Ottoman rebellions. In this respect, if it is even unlikely to support the existence of a constant line between Christian and Muslim subjects of the empire as it is the case in the example of Morea, a fully affirmed and unchanging coalition and alliance between janissaries and Ottoman jurists or between absolutists and constitutionalists is largely unsubstantiated. After all they were more likely to change sides as they came from the same cultural background and knew each other very well. Ottoman documents offer numerous example of intimate relations between members of such seemingly distinct and homogenous groups who were indeed much less united and much more fragmented than any previous account has explicitly revealed so far. Obviously, the Ottoman subjects in question did not think of themselves as absolutely belonging to a specific entity whose interests were more important than anything else. ${ }^{53} \mathrm{In}$ stead, individual self-interest appears to have been the main catalyst to detriment of collective interests within the groups as it was often the case in many other Ottoman uprisings that took place between 1550 and 1821, too.

In the same way, there was not a strict line totally separating Muslims from Christians due to the Morea Rebellion in the eyes of contemporary Ottoman officials and dignitaries even long after the suppression of the uprising in mid1770s. Before and during the rebellion Ottoman attitude towards the Christian reaya in general and the koçabaşıs of the Morea (non-Muslim administrative leaders) was neutral and the state did not regard them as a threat to its very existence. Instead, they were still entrusted with many administrative and financial duties. It is true that as the conflict between Muslim and non-Muslim subjects of the empire reached its apogee as it was the case on the eve of the Greek rebellion of 1821 and thereafter, the state found Muslims more faithful in opposition to the zimmis (protected non-Muslim subjects of the empire). Nonetheless, one should not exaggerate this changing environment in favor of Muslims. Immediately after the Morea rebellion of 1770 and many other rebellions of its kind thereafter, the Ottoman state did steadily its best to gain continuing support of non-Muslim subjects of the empire and to reintegrate them into the Ottoman system once again. To give one example, it was not roughly until the Greek Independence War of 1821 that the Ottoman intellectuals decided not to let leading Greek koçabaşıs to take part in state administration any more. ${ }^{54}$

53 Gündoğdu, "A Boiling Cauldron", 73-80.

54 Gündoğdu, "A Boiling Cauldron”, 80-8I. 
We have briefly revived Ottoman historiography of rebellions published in the last more than fifty years in order to bring our attention to its common shortcomings and inability to construct any reasonable argument for that matter. Taken all into consideration, the Ottoman scholars of rebellions seem to have roughly developed three distinct approaches, i.e. traditional, idealized and restricted in the course of time. The traditional approach inclines to explain everything within the paradigm of "Ottoman decline." That is, unlike the previous centuries the empire step by step lost its former talent and strength to get rid of rebellious and unwanted members of the society, which opened the way of total destruction of the empire as the time went by. Accordingly, unlike European states starting the seventeenth century onward the Ottoman Empire was no longer good at coping with upheavals and insurgents of the early modern world despite the facts that they all shared many common problems and pitfalls. The former gained strength and each decade became more and more united, and the latter not only gradually lost its former power but also largely disintegrated after plethora of serious rebellions the empire had to face with in the long run. Separatist rebellions like sufi insurrections of sixteenth century, which did not stem from state pressure or injustice but rather had an ideological background and messianic inspiration should also be seen in this line. After all, they were neither conciliatory nor moderate in the sense of trying to cope with the Ottoman system once more and the empire was less and less able to stop their devastating effects to detriment of the Ottoman state. Therefore, they did play an important role in this unstoppable decline of the empire, so to speak.

The idealized approach, however, argues that the Ottoman Empire and its rebellious subjects were the very reason why the empire succeeded in surviving the periods of crises. The empire was more than successful to use the tool of negotiation with insurgents and they were more than happy to be reintegrated provided that they got a better position within the state apparatus. ${ }^{55}$ Correspondingly,

55 More or less, they are not able to offer any alternative theory to their shared misperceptions and misconceptions. For instance, all are in agreement that the Ottoman statesmen was quite capable of controlling and manipulating rebels and bandits through deals, bargains, employing the tool of negotiations, offering them more favorable official status and so on. This striking success of consolidating and maintaining Ottoman prominence over society must not have inevitably come from state skill and discipline, however. Alternatively, human nature might provide a better and less problematic answer for the question why Ottoman rebels were so easily absorbed into the fabric of the state again. Needless to say, insurgents were more ready and willing to accept immediate little rewards rather than taking a lot of hard work and continued 
as "the sole center for rewards and privileges" the Ottoman Empire was not only as sophisticated as European states (and even more successful than the West until the very end of eighteenth century) but also quite good at adapting to new eras for the very purpose of maintaining its integrity and of surviving severe setbacks. This approach finds no reasons to posit that the empire experienced any sort of state breakdown (but only temporarily setbacks) in direct opposition to the "decline paradigm" of traditional approach. The idealized approach also likes to regards Ottomans as perfectly homogenous, separate and classified entity based on strictly divided religious, national or any other group identities of the time. Accordingly, they either incline to ignore numerous exceptions which do not really get along with the arguments they make, or to view them as causes for integration and success rather than as threats for Ottoman integrity.

Any attempt to define Ottoman subjects clearly defined according to certain group identities, membership or sense of belonging in a specific community is problem -ridden and potentially unreliable. Based on their own particular sources, however, the first two approaches are more eager to generate a coherent plan for their arguments and put the ideas into some persuasive order, there emerges frequently some items, which do not easily comply with some of their arguments. As a result, they simply put them aside and are not even prepared to incorporate them at a later stage into their writings because they do not fit logically into the point they would like to make. Leaving them out of their discussions and ignoring them sometimes reduce the credibility and acceptability of their arguments extensively that one should not take them into consideration at all. Flexibility and transparency within and outside vaguely defined groups, factions or entities not only constitute a more solid argument to establish but also are easier to be proven in the light of new Ottoman documents, which are often full of contradictory examples to the general discourses present above. At this juncture, in the last decades we start to see the last approach to both, which not only accepts the

efforts to get a bigger price or going all the way through and risking everything for an undefined radical dreams or for the sake of imagined group identities to whom he is often and strictly claimed to belong. Soon, they were even appropriated by the state for purpose of state consolidation and peripheral control, which was otherwise less likely to be achieved in the early modern period when the state had neither strong state institutions nor money to maintain a tight control over society. In this respect, many studies taken into consideration in this approach might be either totally rejected or substantially reconstructed for more reasonable and acceptable analyses in the long run. 
shortcomings and limitations of both traditional and idealized accounts but also offers an alternative perspective to the Ottoman rebellions at issue.

That is to say, the restricted approach provides more vivid examples of complex and multifaceted nature of Ottoman rebellions and by doing so it willy-nilly abstains from making any general statements that the traditional and idealized approaches gladly like to do. On the one hand, it brings the traditional and idealized explanations together and tries to benefit from their advantages and to learn from their weaknesses. On the other hand, however, unlike the formers it is not that eager to draw any strict line within the Ottoman society, which after all neither match up with historical accounts/facts of Ottoman rebellions nor pass the test of historical criticism and scrutiny during the time periods under consideration. Not surprisingly, having accepted the complexity and intricacy of Ottoman rebellions it offers much more restrictive assumptions than previous approaches and that is why we name it as restricted. To be exact, by denying most repeated causes and most widely accepted motives of Ottoman rebellions it provides us with new terminologies to the old discussions such as constant switch of allegiance and shifting sides, transforming an archenemy into friend or a friend to an enemy, flexibility and transparency within and outside vaguely defined groups, factions or entities, the selective group identify relied on blood ties or family, lack of any united/homogenous group people strictly delineated according to Ottoman subjects' religion, race or nation, and so on. Instead, the Ottoman society of the time is rather described as being much less united and much more fragmented than any previous approach has explicitly revealed so far. As an alternative to former arguments the restricted approach thinks of individual self-interest as being main catalyst to detriment of collective interests within the groups as it was often the case in many other Ottoman uprisings that took place between 1550 and 1821 . This vagueness seems to constitute not only a more solid argument to follow but also is much easier to be proven in the light of new Ottoman documents, which are often full of contradictory examples to the general discourses present above.

Last but not least, there is no doubt that the Ottoman rebellion as a subject of study has not been still well researched yet. In this paper, we have investigated and criticized the studies of the most famous scholars, which were one way or another conducted for the benefit of the Ottoman rebellions. Examining their arguments not only allows us to reveal the main sources for today's writings but 
also gives us a chance to compare these arguments meaningfully with one another. The number of such sources might be increased but what we have already taken into consideration for the sake of this article is enough to bring into the sharp relief the contemporary understanding of the Ottoman rebellions between 1550 and 1821. More importantly, however, their arguments, which almost totally define the limits of the material known to us at present, is full of misconceptions and absurdities. A comprehensive study conducted on notable figures of each rebellion seems to be essential before we are able to offer any sustainable prospect for the Ottoman rebellions. In the meantime, however, we can take the full advantage of previous works, each of which highlights certain valuable aspects of the Ottoman rebellions. At this juncture, our evaluation of former works has proven that the restricted approach is apparently the best departure point to begin with as we deal with the Ottoman rebellions in the early modern period. In other words, our general analysis of all these sources proves that each argument not only has its own unique and dynamic features but also offers some valid and useful hints that can be benefited for the discussion of other rebellions in the Ottoman Empire, as well. Accordingly, our deductions should be still at best tentative - new archival sources or findings can easily lead to general theories being revised or even totally rejected. Many studies above offer good examples of how theories fall short of capturing the intricacies and complexities of the Ottoman rebellions under consideration here. As it is often the case in the Ottoman studies what we have in mind does not match up with what the evidences and sources tell us about a specific research like Ottoman rebellions. On balance, we should first be quite flexible and open to consider, evaluate and integrate alternative explanations or interpretation together with the sources that support or challenge the widely accepted arguments mentioned above. 